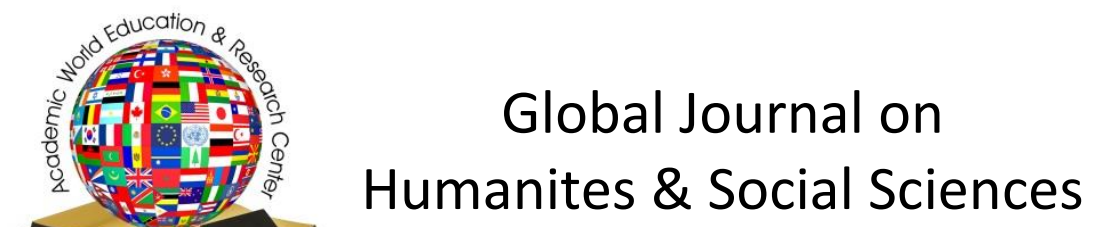

Issue 4 (2016) 01-07

Selected Paper of 4rd World Congress of Administrative and Political Sciences, (APDOL-2015)

26-28 November 2015, Rome, Italy

\title{
Human rights aspects of european foreign policy
}

Ali AYATA*, Department of Political Science and Public Administration, Faculty of Economics and Administrative Science, Bilecik Seyh Edebali University, Turkey.

\section{Suggested Citation:}

Ayata, A. (2016). Human rights aspects of european foreign policy, [Online]. 04, pp 01-07. Available from: http://sproc.org/ojs/index.php/pntsbs

Received June 05, 2015; revised August 23, 2015; accepted September 23, 2015. Selection and peer review under responsibility of Prof. Dr. Andreea Iluzia IACOB C2016 SciencePark Research, Organization \& Counseling. All rights reserved.

\begin{abstract}
The development policy of the European Union is a policy area that has developed rapidly, especially after the Cold War and the conflicts between Eastern countries. In the 1990s, the EU issued a development profile and started the human rights and democracy concepts into the Treaty of European Union officially as guiding principles in its foreign policy. Even before the importance of human rights and democracy in the founding treaties of the European Union was mentioned, strengthening the identity of the European Union could be brought at the international level from the start with respect for these criteria together, because these criteria were the grounds for the EU. The specific aim of this work is to consider the human rights dimension of EU development, cooperation and also some related policy issues and implementation problems in practice, which are considered in theoretical approaches in the study. It should be also noted that while the EU acts as an institution and also relief organization, it makes use of its own funds and budgets, not its Member States. Within this context, the activities of the Union to promote human rights could be interpreted as cultural imperialism.
\end{abstract}

Keywords: Human Rights, European Union, Foreign Policy, Cultural Imperialism.

* AdDRESS FOR CORRESPONDENCE: Ali Ayata, Department of Political Science and Public Administration, Faculty of Economics and Administrative Science, Bilecik Seyh Edebali University, Turkey. Tel: +90 2282141195 . : ali.ayata@bilecik.edu.tr / 


\section{Introduction}

Human rights are complex rights, which are comprised between morality, politics and law. Mounted in a nutshell, it is morally justified claims, which are formed by means of policy-making and implementation rights "positive". However, the specific design of the human rights claims in fundamental rights and international law binding standards is subject to historical and cultural influences, and is subject to changes given case.

The development policy of the European Union is a policy area that has developed rapidly, especially after the Cold War and the countries of Eastern conflicts. In the 1990s, the EU issued a development profile and started the human rights and democracy to the Treaty on European Union officially as guiding principles in its foreign policy to be considered. Even before the importance of human rights and democracy in the founding treaties of the European Union (then the European Community) was mentioned, strengthening the identity of the European Union could be brought at the international level from the start with respect for these criteria together, since it around the founding values of the community concerned (Algieri, 2010).

Today there are several legal-bases for development cooperation and development aid from the EU. With the entry into force of the Regulation on the European Initiative for Democracy and Human Rights, which had relied directly on Article 6 of the Treaty on European Union and the human rights precepts, there was the first legal basis for the "promotion of a culture of human rights" and a "democratic process "on the part of the European Union. In 2006, this regulation was reversed and instead a European Instrument for Democracy and Human Rights introduced, which is a tool for the promotion of democracy and human rights in third countries. Now count the respect for human rights, establishment of democratic participation and ensuring the so-called "good governance" on the major objectives and criteria for cooperation policy and development assistance from the European Union (Benedek, 1997).

The focus was on the first application of negative actions. Political conditionality was widely known for the first contracts with third countries after the introduction of human rights as principles for foreign policy towards third countries. These included, for example, the reduction or even suspension of cooperation by the violation of human rights or the breach of the principles of democracy in the country. Then, the positive measures have been introduced and the EU committed itself to set the state and non-state actors to the political, institutional and legal reforms and contribute thematic and geographical priorities (Haratsch, 2003). Through the promotion of human rights, the EU and the Commission contributed aware at the UN Millennium Development Goals. So it was that the Commission adopted a series of measures to support the achievement of these objectives. Today, the Development Cooperation of the EU, Europe Aid is called external aid programs to the Commission in over 70 countries in the world.

In this work it is superficially about the promotion of human rights in development co-operation of the European Union. The specific aim of this work is to consider the human rights dimension of EU development cooperation and some related thereto policy issues and the mention of implementation problems in practice. The centerpiece is a developmental approach, which prompted me to concern myself with the theoretical approaches within the context of development policy. In addition, it should be noted that this is the EU as an institution, as an organization and development aid, which, only from the funds and budgets of the Union, but not on its Member States The promotion of human rights in development cooperation of the EU is interpreted in terms of cultural relativistic theory and cultural imperialism. 


\section{Development of Human Rights in Europe}

It is not easy to elicit the roots as well as the exact origin of human rights and thus to identify clearly. However there is enough evidence then to say with certainty that the origins are clearly to be found in Europe. In this time secular dominant ideologies and religions are based on ethics and morality, we see a clear link with the values of the ancient world and their philosophy and thus recognizable roots of today's human rights. We have found that all ethical and moral traditions that date back to ancient times constitute the common good or the good as the common denominator. On the other hand, we see in the laws of Hammurabi (Hindu), Buddhist scriptures, Greek and Roman laws that equality is not implied. Thus, women, slaves and landless were a very long time the powerful nobles, oligarchs and haves not equal, but usually excluded from society (Haratsch, 2003).

For the further development of the universal declaration of human rights, the "Western" flows and their ideologies were able to prevail and shown to be dominant in what eventually led that have shaped the modern conception of human rights and their universalism. The achievements of the European Enlightenment and the related expansion of Western power you can certainly rate as a milestone for our current understanding of human rights, considering that they have prevailed against influences from China, India and the Muslim world (Benedek, 1997).

Human rights are as a legal entity, philosophical belief, or as fundamental rights codified characteristics of the 18th - 20th century. The words that are based on today's human rights, dated as Latin words from ancient times. However, you do not have the same meaning and today bear a different weight than envisaged because they were often used in other contexts (Schmidt, 2004).

The Latin term "ius humanum" is used today brisk, although less in its original, but rather in its "modern" form as a synonym for human rights. From ancient times still further terms are assumed to be actively used today, such as religious freedom (libertas religionis) and human dignity (dignitas hominus). Human dignity is a term from the Stoic anthropology that brought the importance of morality in ancient times, in contrast to the post-classical expression. The Stoic philosophy emphasized the human dignity and the fact that all people are reasonable in the same way and should therefore enjoy the same rights (Haratsch, 2003).

\section{Human Rights Aspects of EU Foreign Policy}

Human rights take in several areas of the EU's External Action Service a central role. They affect both the foreign and trade policy, development policy, as well as diplomatic and security policy of the EU. Although the European human rights have a geographical coverage within the borders of the Union on the basis of the ECHR is the ideology of human rights and human rights protection together with the promotion of democracy is one of the central concerns of the $\mathrm{EU}$, and outside its borders (Weidenfeld \& Wessels, 2011). It is not a specific coordination, but rather common positions, which are formed by common interests and approaches and so unanimously presented to the outside. This is mainly an intergovernmental cooperation in which the management of the common foreign and security policy shall be done by the Council of Ministers, while the foreign trade relations and development co-operation is supported by the Commission (Fröhlich, 2014).

With the integration of human rights into domestic and foreign policy matters with third countries, the Union has the importance of these rights once more explicitly underlined and so strengthen human rights with their positions in all areas of their acting out. Thus, the objectives of the European human rights policy are mainly the respect for human rights within the Union's borders and to third countries around the world (Hartmann, 2009).

Even before the latest Treaty of the European Union, human rights were a special part of the EU and its policies. The Treaty of the European Union has been determined that human rights are one of the main principles of the Union and the Member States are obliged to follow them, because it is the primary law of the EU in the principles (Weidenfeld, \& Wessels, 2011). The connection to the human 
and fundamental rights and democratic principles can be seen in the two constitutional treaties of the EU. Seen for example in Articles 6 and 7 of the Treaty on European Union (the violation of human rights can lead to recommendations and sanctions), as well as in Articles 18 and 25 of the Treaty on the Functioning of the European Union. In Article 25 of the Treaty on the Functioning of the European Union is cited:

\section{paragraph 1)}

(Treaty on European Union, title V, Chapter 1, article of 21

On the basis of the above article it is shown that the EU is bound not only in domestic but also in foreign affairs in human rights. Racism, xenophobia and discrimination are thus part of the EU's human rights protection.

The EU's foreign aid allocation, including the political and decision-making division, can be classified into five separate departments: External relations, neighborhood policy, trade relations, EU enlargement, Europe Aid - Development and Cooperation and Humanitarian Aid. After the Treaty of Lisbon entered into force, the European External Action Service (European External Actions Service) took over the responsibility and the organization of development cooperation. Before the Treaty of the European Union, the department "Development and Cooperation" for the implementation of development aid was responsible (Leiße, 2010). It is shown how the Union acts as a political actor. These are the details about the foreign policy active EU whose actions go out into the world on a common policy of the 28 states. Much more important, in this context, however, the point of attachment to human rights and the EU policies. In all of these policies is a human rights thread to find, as they deal with human rights as a prerequisite or the promotion of human rights (Algieri, 2010).

European foreign policy is based on the EU's activities that take place outside the borders of the Union or relate to the third countries. In other taken including those States understood that do not belong to the Union, with which the Union is to build a relationship. In the EU decision, the foreign economic relations, development cooperation and the EU's foreign relations are reported as the main components of European foreign policy (Fröhlich, 2014).

The external relations are one of the policies of the EU. This policy area includes the Commission and its initiative. The common foreign and security policy, together with the European security and defense policy a part of foreign policy and the Union stands as a means for external relations available. You will be decided within the Council of Europe and operates from the high representatives of the Union. A "foreign policy" of the EU to as "the sum of all official foreign relations are understood to be entertained by an independent actor in international relations." Here, the Union is seen as an independent actor and thereby allows the inclusion of all of its institutions and conducting mechanisms. In addition, it is "very efficient" with the quantity of their policies in order, since in this way the external relations policy is understood as the sum of the actions rather than each individual. Furthermore, foreign policy, the "common handling of the international environment," with a number of players who are not in the territory of the Union to be understood (Schmidt, 2004, 295). The Union's action is an interest-driven and purposeful action in this case. Foreign policy can be characterized as a development process, "are designed in the course of the external activities of the actor, regulated and controlled to agree objectives can be protected and continued." 
The European Neighborhoods Policy is one of the EU policy areas in which human rights play a serious role. It was called in 2003 to maintain relations with all neighboring countries of the Union, including enabling cooperation. The European Neighborhoods Policy should, strictly speaking, build relationships with the direct and indirect neighboring states of the EU, but it does not include the enlargement policy (Türkmen, 2003). The policy should provide for better relations with neighboring countries after 2003. In the context of the EU's Neighborhoods Policy bilateral Action Plans (ENP action plans) are defined. There, the objectives of the relationship between the neighboring countries and the EU to be strengthened in order to achieve political and economic goals together. Human rights and democracy are always part of the objectives and also help through the European Neighborhoods Policy flowing EU assistance to facilitate the promotion of human and fundamental rights, the rule of law and democracy (Girardet, \& Nortmann, 2005).

In 2006, the European Neighborhoods and Partnership Instrument came into force, which is intended to achieve the objectives of the European Neighborhoods Policy Action Plans. This is the group of states, but the neighboring non-candidate. For the neighboring countries that are candidates at the same time, there is the Instrument for Pre-Accession Assistance (Göztepe, 2008). The implementation of the EU assistance follows finally through dialogue, projects and programs. Furthermore, the main focus of cooperation in the fields of justice, the fight against terrorism and drug trafficking and institutions reform and promotion of human rights.

The elements of the Neighborhoods Policy, is the bilateral action plans and other bilateral agreements with each European Neighborhoods Policy partner. The most important resources of the European Neighborhoods Policy, the bilateral dialogue between the high political representatives and subcommittees should be mentioned that deal with specific topics in the course of the implementation of the European Neighborhoods Policy in neighboring countries. This includes human rights. Moreover, the European Neighborhoods Policy is controlled by various committees and subcommittees that were built within the framework of bilateral partnerships and cooperation or association agreements. The strengthening of democratic and constitutional structures are the utmost priorities of relations and cooperation between these countries and the EU. The neighborhood policy has grown in importance since the 1990s, as the EU wants to establish a stable environment and maintain good social and economic relations with its neighbors. Therefore, the Union has invested a lot of money into projects that stabilize these countries to democratize and integrate (Algieri, 2010).

Human rights issues are in the field of humanitarian aid were particularly important and at the same time very often questionable and criticized. Apart from the Member States who send their troops if necessary in the crisis areas, the EU is active as an actor (Schäfer, 2012, 89). The Facility Humanitarian aid financial aid, goods, services and technical assistance to the population in the crisis areas are provided. It is also one of the most citizens' actions at the international level. After the Cold War all had a hope of peace. However, ethnic nationalism, a term that was later shown its true face, took place in the 1990s, when humanitarian aid was used for the first time in the Second Gulf War. The violent and bloody conflicts and civil wars broke out later in Yugoslavia and then in the other part of the former Soviet Union. The EU had to react quickly to stop human rights violations. In addition, these were by States in their immediate vicinity, so it was just as vulnerable (Weidenfeld, \& Wessels, 2011, 148)

As the foreign policy and the east policy of the Union have changed, we can see well in the following example: The EU until departure based on war helper monetary policy towards Eastern Europe supported economic growth as well as the political and democratic transition. In the 1990s, the EU contributed to a new page and made an era of European integration known fact that the countries of Eastern Europe were virtually allies. It was from the Union point of view, the best way to a stable and peaceful region, through the conflicts, the Union could be threatened potentially itself. To prevent this, the EU decided to admit these countries a chance at a Union accession and this conflict to act preventively against (Beck, \& Piazolo, 2008). 
The EU decided then, this conflict prevention in foreign policy, which has already supported for this time on human rights and promotion of human rights included. The European Council published in June 2002, "Implementing the EU Programs for the Prevention of Violent Conflicts", on the grounds that the large number of concrete measures that have been used successfully by the Union in the Balkan conflict represent a successful example of conflict prevention and this have helped to develop an instrument for conflict prevention (Göztepe, 2008).

A specific early warning system, instruments of short-term and long-term prevention and intercultural dialogue are measures used by the EU for effective conflict prevention. The document is to say that the "EU to act on democratic values and respect for human rights, political and moral obligation based as a successful example of conflict prevention [is] to prevent the tragic consequences of violent conflict."

These efforts of the EU to avoid potential conflicts and inhibitions cannot be discussed here, if no direct relationship to the activities of development policy is provided. This example also certain incoherence can be seen as the measures of humanitarian aid are not linked directly to the activities of the European Aid, although they have a common basic human rights and are used for the same purpose (Beck, \& Piazolo, 2008). To this purpose include peace, rule of law and respect for human rights, which eventually will lead to a certain degree of development in the country. It comes back before the conflict between development and human rights, which shows us how interdependent the two concepts really are.

\section{Conclusion}

After the number of EU policies which have human rights as a target base or starting point, it is clear to see that the importance of human rights is not only important for the EU inward-oriented policies, but also for foreign policy. Human rights are in the neighborhood policy to find help in the enlargement policy, development aid, trade policy and humanitarian. In some policy areas they are even listed as a prerequisite, as that is the case in the EU's enlargement policy, as the candidate countries must meet, inter alia, a degree of respect for human rights. In trade agreements with third countries, the Union introduced a human rights clause already in the 1980s, so the trading partners are dependent on respect for human rights (Schäfer, 2012, 29). There is a controversy in the economic world, because this clause was negatively formulated at the beginning and the negative connotation has remained upright until today. With regard to development aid, human rights are an integral part since the creation of Europe Aid. In Europe Aid Office progress and a good idea for the distribution of tasks to be seen in order to achieve better results in development cooperation in general.

The EU needs to develop over time modernity, thus adapt the instruments and the resulting projects to the type of extortion or the violation of human rights with their projects for the promotion of human rights. So a EUR 6 million worth project was planned for the years 2013 to 2015, the support to bloggers sports journalists, trade unions, non-registered non-governmental organizations, organized pro-democracy movements weak that operate in certain dimensions in the critical political context gives. Today's time to bring in a dictatorship countries uncertainty on all those who potentially could talk against the state and the freedom of the media, opinion and expression, thereby impairing. The EU will respond accordingly and developed projects that relate Space or political oppositions on freedom of expression in Syber. Support includes, for example, the financing of the project activities, material support, operating costs, etc (Leiße, 2010, 79).

A structural problem of the EU's human rights policy is to embed human rights in the European model of democracy, market economy and regional integration. The question of whether this model and thus is of universal application exportable, remains to be answered (Reisoglu, 2001, 47). Another factor is that often the unwillingness of third countries to political and institutional reforms. States adopt EU rules only if the benefits they expect it, the cost of implementing predominates. This is also the reason why human rights policy towards candidate countries has so far been the most successful. 
As a general willingness of the EU to an increased awareness of the situation of human rights and promotion of human rights in external relations cannot be disputed, some suggestions for improving the coordination and the use of instruments are given in conclusion.

\section{Reference}

Algieri, F. (2010). Die Gemeinsame Außen- und Sicherheitspolitik der EU, Wien: Facultas Verlags- und Buchhandels AG.

Beck, T., \& Piazolo, M. (2008).

Fhvr Verlag.

Benedek, W. (1997).

, In: Liebmann, Andreas / Amon, Werner (Hrsg.) Dimensionen 2000. Umwelt, Friede und Entwicklung, Wien: Holzhausen, 145-156.

Fröhlich, S. (2014).

Verlag Springer VS.

Girardet, K. M., \& Nortmann, U. (2005). Stuttgart: Franz Steiner Verlag.

Göztepe, E. (2008).

Seçkin Yayıncılık, Ankara.

Haratsch, A. (2003).

Würzburg: Verlag Königshausen \& Neumann GmbH.

Hartmann, J. (2009).

Frankfurt, New York: Campus Verlag.

Heinz, S. W. (2004).

In: Selchow Ulla/Hutter, Franz-Josef: Menschenrechte und Entwicklungszusammenarbeit. Anspruch und politische Wirklichkeit, Wiesbaden: Verlag für Sozialwissenschaften, 69-86.

Leiße, O. (2010).

, Wiesbaden: Verlag für Sozialwissenschaften.

Reisoglu, S. (2001).

, Beta Yayınevi, İstanbul.

Schäfer, M. (2012). Menschenrechte und die Europäische Union: Geschichte und Gegenwart der Menschenrechte in Europa, Diplomica Verlag.

Schmidt, S. (2004).

, In: Selchow, Ulla/ Hutter, Franz-Josef: Menschenrechte und Entwicklungszusammenarbeit. Anspruch und politische Wirklichkeit, Wiesbaden: Verlag für Sozialwissenschaften, 285-299.

Türkmen, F. (2003).

, B. Dedeoğlu (der.), Dünden Bugüne Avrupa Birliği, Boyut Kitapları, İstanbul, 133-164.

Weidenfeld, W., \& Wessels, W. (2011).

, Baden-Baden: Nomos. 